\title{
Introduction. Corruption and the rise of the fiscal state
}

Book or Report Section

Accepted Version

Felix, J. and Dubet, A. (2018) Introduction. Corruption and the rise of the fiscal state. In: Felix, J. and Dubet, A. (eds.) The War Within: Private Interests and the Fiscal State in EarlyModern Europe. Palgrave Studies in the History of Finance. Palgrave Macmillan. ISBN 9783319980492 doi: https://doi.org/10.1007/978-3-319-98050-8 Available at https://centaur.reading.ac.uk/79001/

It is advisable to refer to the publisher's version if you intend to cite from the work. See Guidance on citing.

To link to this article DOI: http://dx.doi.org/10.1007/978-3-319-98050-8

Publisher: Palgrave Macmillan

All outputs in CentAUR are protected by Intellectual Property Rights law, including copyright law. Copyright and IPR is retained by the creators or other copyright holders. Terms and conditions for use of this material are defined in the End User Agreement.

www.reading.ac.uk/centaur

\section{CentAUR}


Central Archive at the University of Reading

Reading's research outputs online 


\section{Introduction.}

\section{Anne Dubet and Joël Félix}

State-building is one of the most distinctive and enduring features of early modern European history. To explain this phenomenon historians, sociologists, economists and political scientists have successively developed and refined analytical models of state formation. They have formulated a number of concepts, such as the confessional state (Oestreich) the tax state (Schumpeter 1918), the fiscal state (Bonney 1999, Yun-Casalilla and and al. 2012), the fiscal-military (Brewer, 1989) or fiscal-naval state (O'Brien 2005), the bureaucratic state (Weber 2013), the contractor state (Palmer, in Bowen 2013: 241), and so forth. These concepts do not merely serve to reflect specific methodologies, fields of interests or problems of empirical validation when put to the test in the study of specific polities (city-state, territorial state, composite state, empire), regimes (absolute or limited) and organising principles (dynastic, patrimonial, bureaucratic, etc.). To an extent the concepts on offer account for the radical nature of the transformations at work in a period which had to absorb the impact of the Reformation and long-term changes encapsulated in the scientific revolution, the military revolution, the financial revolution and, of course, the development of capitalism in a world economy. They also reveal the extent to which state development, in the era before the fully-fledged Nation-state and modern parliamentary regimes, was a slow process, usually path-dependent and involving incremental change, the scope and intensity of which depended on a multiplicity of variables, most notably location, time and agency (Ertman 1997). If international competition and domestic conflict over access to the sources of power played a vital role in shaping different types of regimes, it seems now clear that their characteristics and resilience hinged upon a complex mix of social, economic, political, legal, religious and cultural components (Braddick 2000, Gorski 2003).

As a response to exogenous and indigenous challenges, state formation in general, and the rise of the fiscal state in particular, was a conflictual process at its heart, with short and long-term transformative effects. Most obviously, international warfare altered the balance of power in Europe, occasionally destroying and creating states, and remodelling social relations. Tilly's aphorism that 'states make war and wars make states' nicely sums up a seesaw model to describe what seems like the inevitable evolution from the end of the Middle Ages onwards. The argument, however, remains a relatively crude explanation and has been further explored to explain successes and failures, in particular to explain state's successes on the battlefield depended upon access and organisation of economic and capital markets (Tilly 1992). Still, the circularity of the initial aphorism tends to subsume social experience in the state, the end of history being either a 
situation of total war and potential annihilation of the enemy, or of unstable peace under hegemons and coalitions.

While scholarship remains broadly focused on the roots of state's successes and failures across time and space, with long-term political stability and economic growth as yardsticks, much of the new research is concerned with the institutional and cultural foundations rather than the material basis of the state's projection of power through sheer accumulation of military or naval forces (Acemoglu and Robinson 2012). Although mobilisation and end use of resources are two sides of the same coin, management of warfare was also about solving tensions between demand and supply, and of course legitimacy. In this respect, the extraordinary needs imposed by warfare did not only call for a fiscal-military state, capable of raising money and credit to fund war operations, but also a contractor state to organise procurement. In other words, the sources of power rest on the interplay between coercion, or use of the legitimate monopoly of violence by the ruler, and collaboration, or the relation between public and private interests, to protect society and promote the common good.

Many recent works concerned with state-building in early-modern Europe have highlighted the crucial role played by various private groups in helping rulers access larger pools of resources to display their personal glory and sustain their dynastic interests. However, as Parrott (2012) observed in the case of the business of war in the age of the military revolution, a humanist tradition sees the connection between private and public interests as essentially a fraught one, which prioritized individual profit over the ruler's authority and the quality of service. Recent research on corruption and anti-corruption in history have reinforced the complex nature of the relation between the two spheres by showing, on the one hand, that their separation was a relatively recent development, which built upon more precise definitions of corruption, but, on the other hand, that the long-term evolution was anything but linear (Kroetze and al. 2017). In medieval and early-modern Europe, for instance, introduction of venality, or the sale of offices by rulers, coincided with specific rules for appointment, transmission and accountability of offices. Various works also argue that criticisms of the patrimonial nature of public functions were not essentially meant to target venality as such but served political strategies aimed at regulating access to offices (Artola and Dedieu 2011). In addition, research on the techniques, objectives and impact of audits of officers who collected and spent tax revenue suggest that the procedures did not seek to prohibit profit in the management of public monies but to distinguish between lawful and unlawful benefits (Legay ed. 201, Dubet and Legay 2011) especially when set in the context of the bitter rivalries pitting financial interests and political factions (Graham 2015; Andujar Castillo and al. 2016, Kleer 2017). 
In the wake of the financial crisis of 2007-08, and the series of scandals relating to corporate sectors and private actors, it seemed appropriate to explore the role of institutions in maintaining trust and fighting corruption, as well as in promoting political stability, economic growth and equality of opportunities. To this effect, this volume, which proceeds from an international conference organised at the University of Reading on 4-5 December 2015, co-funded by ESRC and IUF, investigates the issues of trust and corruption in the management of tax revenue and expenditure in early modern Europe. As mentioned, the subject of corruption has attracted renewed attention in a number of recent studies with emphasis on cultural, political and, lately, intellectual dimensions of corruption (Waquet 1992, Storrs 2008, Hoenderboom and Kerkhoff 2008, Buchan and Hill, 2014). Yet on fiscal corruption specifically there is no specific study to match the important work done in particular on venality and officers in early-modern Europe (Andujar Castillo and Ponce Leiva 2016, Doyle 1996 and 2000). This volume proposes to fill this gap by exploring the discourses and practices of the various actors involved in fraudulent activities and their denunciations, as well as the rulers' and the states' responses. From the outset, two common pitfalls have to be avoided. Firstly, assessing the action of early-modern agents on the basis of a modern definition of corruption risks promoting an inaccurate teleological model of the phenomenon, and discarding evidence of repression of corruption, for instance through trials and visitations, as historically meaningless or pointless attempts to engage with structural causes. Secondly, it risks fuelling the common fantasy about a conspiracy by early-modern elites accused of hiding their personal greed and moral remorse behind the ethos of noble and free service when consciously committing a crime, an early-modern crime which is none the less set against modern standards. This volume is more interested in examining when and why social actors started considering the ethos of service and the rewards of gifts as the intolerable expression of elite domination and exclusive access to money and honour.

To overcome such pitfalls, this volume pays special attention to early-modern fiscal actors through analysis of discourses and practices of fraud and corruption. Discourses are analysed in varied contexts, essentially on occasion of political conflicts, usually coinciding with attempts to instrumentalise anti-corruption within and outside institutions, and judicial procedures over accusations of fraud. Here, the work of theoreticians is supplemented with the views of various individuals, coming from diverse social and political groups, for the purpose of identifying whether there was an early-modern culture of corruption in general, and of corrupt actions in particular. Practices cannot be separated from discourses, particularly in the case of denunciations of others' malfeasance. For this reason, the chapters in the volume are essentially case studies. Their authors did not seek to establish a catalogue of repetitive notions about corruption which were often foreign to the political culture of early-modern agents. On the 
contrary, corruption and its repression are studied through primary sources: law and legal treatises, documents on fiscal decision-making and arbitration between private/public interests, judicial sources produced for trials, accounts, etc.

The volume spans the last two centuries of the Ancien Régime and maps onto a vast geographic area encompassing Southern Europe (Spain) and Scandinavia (Sweden), including Great Britain, France, the Southern Low Countries, the Dutch Provinces, Prussia and Bavaria. These territories include both Catholic and Reformed confessions, absolute monarchies (Spain, France, Prussia, Bavaria) and limited parliamentary regimes (England, Dutch Provinces, Sweden). The case studies examine different types of corruption pertaining to the collection of taxes and the payment of state expenditure, the issuing of debt and circulation of financial assets, coinage and counterfeiting, and accountability in general. They also examine different levels in the principal-agent relations: government and governed, government and fiscal agencies, fiscal agents and employees, governed and fiscal agents.

This volume does not claim to be an exhaustive history of fiscal corruption in early-modern Europe. Yet the variety of the approaches of its ten cases studies, combined with the results of recent literature, bring significant new knowledge which helps map out a number of key notions about the relations between the fiscal state, its agents, and the public. The following table is an attempt at a typology of principal/agent relations and their long-term evolution, or, as it were, a model of fiscal ethics. A left-to-right reading of the table would certainly open to the accusation of a linear and teleological interpretation, which, as we will see, is not supported by the findings for this volume. Work on the Netherlands (de Vries and Van dre Wroude 1997) and Britain (Hoppit 2013) cast doubt about the validity of an all-purpose of the Old Regime (Doyle 2013) throughout earlymodern Europe prior to 1789 , as a means to account for crises and modernisation of traditional structures. 
Table 1. Mapping the war within: the ethics of public good and private interests

\begin{tabular}{|l|l|l|l|l|l|l|}
\hline \multicolumn{5}{|c|}{ EARLY MODERN AGE } & \multicolumn{3}{c|}{ MODERN AGE } \\
\hline & Agent 1 & Principal & Agent 2 & Agent 2 & Principal & Agent 1 \\
\hline & Stage A & Stage 1 & Stage A & Stage B & Stage 2 & Stage B \\
\hline Subject & $\begin{array}{c}\text { Early- } \\
\text { modern } \\
\text { state }\end{array}$ & Fiscal agent & Fiscal agent & Modern state & Citizen \\
\hline Society & Aristocratic & Dynastic & Plutocratic & Democratic & Republican & Individual \\
\hline Governance & Elitist & Absolute & Patrimonial & Personal & Limited & \\
\hline Ecope & Domanial & Territorial & Intermediary & Direct & National & Local \\
\hline Discipline & Moral & Glory & Profit/gift & Salary & Virtue & Economic \\
\hline Tensions & Inequality & Justice & Venality & Merit & Politic & Self \\
\hline Control & Petitions & Visitations & Account & Contract & Parl. Comm. & Equality \\
\hline Organisation & Rank & Hierarchic & Associate & Bureaucratic & Collegial & Class \\
\hline Character & Friendship & Despotism & Failure & Distrust & Instability & Distrust \\
\hline Organisation & Patrimonial & Mercantile & Monopolistic & Competitive & Liberal & Opportunity \\
\hline
\end{tabular}


Despite its normative aspect, the table should be read with the assumption that definitions of corruption did exist in both the early-modern and modern periods, but that success at tackling it was a complex process, which could be stopped, reversed or pushed, and depended on the interplay of a number of variables.

In this respect, the chapters collected in this volume are testimony to the permanence of concerns about fiscal corruption, of its condemnation and the existence of tools to fight it. While the specific case studies confirm broad failure to remedy unlawful practices or inefficient institutional arrangements, they also show how tensions, at different level of analysis, paved the way for new perspectives on governance of finance, and a willingness to engage with the costs of corruption, especially at the end of the period under study. Altogether, they focus the spotlight on the ways in which cultural, economic, financial, military, monetary, religious and political institutions shaped common or specific attitudes towards fiscal corruption and government finances. In so doing, they address familiar questions about the timing, rhythm, geography and efficiency of change in early-modern Europe.

Although the frontier between public and private interests evolved in the period under examination, nonetheless the relations between these spheres differed substantially from those in our time. Then tax revenue was usually considered as a monopoly of the Prince or his dynasty, in some cases of provinces, but rarely as the money of a sovereign nation. For this reason, zeal in the service of the monarch did not prohibit personal or corporate profit from management of royal funds. This is illustrated by the rapid upward trajectory of the Spanish jurist analysed by Malaprade, the justifications provided by Swedish merchants studied by Winton, the words of cardinal Fleury and Lavoisier on tax farming cited by Felix, or the benefits allowed to businessmen as exemplified by Dubet, González Enciso and Bernsee in the Spanish and German monarchies. These examples imply convergence between the interests of private agents and the ruler's needs, but also between credit and honour (Malaprade, Graham, Winton). Yet the moral dilemmas identified in the English Pay Office (Graham) and the Talhouët scandal (Velde) remind us that the ethics of the private sphere, essentially personal and familial credit, and those of the public sphere, with the rise of the fiscal state and debt, could pave the way for deceptive or honest relations and fiscal policies.

The principle whereby services to the ruler should be rewarded by commensurate profits had important consequences. Firstly, relying upon private interests to fill in ruler's treasury was deemed desirable (González Enciso, Bernsee, Winton, Dubet). Secondly, venality, or the sale of public offices, was not considered reprehensible in principle but could be so considered in fact, when covering abuses, in particular when individuals sold public offices for their personal benefit (Knights 2017). The case study of counterfeit of French coinage evidences 
the existence of such nuances in the definitions of corruption. Thirdly, in absolute monarchies, finances being the preserve of the ruler circulation of accounts was limited to individuals of the highest calibre (Bernsee, Dubet, Graham, Legay), a secretive practice which political economy condemned in rather later times. Velde shows that the transparency and impartiality of the rules established by the Paris brothers to liquidate the System of John Law through a Visa of the debts was relative, the king secretly granting favours to creditors. Even in limited monarchies, like Sweden, where the arcana imperii had to be shared fiscal information remained the preserve of a small and collegial elite (Winton), the tools for fiscal transparency had yet to be invented and implemented (Félix 2015). Moreover, friendship and love, and their manifestation through gifts, presents and patrons/clients relations, were part and parcel of the various mechanisms which linked states and financiers as well as financiers and credit markets to fund expenditure. Corruption applied essentially to the cases of gifts made with dubious intention (subornation, bribery), extortion of money (concussion), lies (to the king or assemblies) and forgery of fiscal documents (Graham, Winton, Velde)]. In absolute monarchies, the king determined rewards to financiers and businessmen, and made these profits lawful (Bernsee, Dubet).

The benefits granted to agents for services on behalf of the king, in particular in collection of taxes, could be financially ruinous (González Enciso) and costly politically (Kerkhoff) for the king and the public. If the largest beneficiaries from the rise of the fiscal state were not necessarily those most widely condemned by public opinion, as in the case of French traitants and tax farmers, the ability to manoeuver and dispense with their services remained hazardous (Félix). Yet, against the background of the English financial revolution, credible commitment and the rise of markets, fiscal policy under Louis XIV and Louis XV raised new questions, both at home and abroad, about the compatibility of the ruler's and private interests, as shown in the cases of currency manipulation and restructuration of royal debts (Legay, Velde).

Early-modern attitudes towards corruption belonged to a world which was fundamentally rooted in inequality. Inasmuch as corruption was defined by the pursuit of private motives through personal actions, the likelihood of accusation of and condemnation for fraud usually depended on individuals' social backgrounds such as, of course, noble status, but also on patronage as well as notions of credit and honour (Malaprade, Winton, Kerkhoff). At this level, differences in the type of regimes and confessions does not seen to have applied, although the humanist concept of virtue, which appeared late in France, became synonym with equality and the cult of nation (Linton 2001, Bell 2009). Meanwhile corruption was not defined only in legal terms, alongside civil law, but also, and at times above all, through a variety of norms: in particular the concepts of justice and fairness, as defined by Christian morals, with their 
connotations of friendship and love, but also canon law and natural law. These conflicting norms could be more compelling than the ruler's law and, as such, justify infraction and escape repression (Velde, Legay).

Yet elites did not consider that all had equal access to these codes of conduct. This reality invites us to scrutiny of arbitration processes at stake in trials of corruption rather than bluntly condemn the inefficiency of judicial repression via measurement of fraud reduction. In general, analysis of the objectives of the parties involved in legal cases concerning corruption has emphasized their symbolic and political dimensions and, consequently, the importance of assessing the efficiency of repression along these objectives. This interpretation helps understand the rationale behind royal clemency (considered more efficient, politically, because linked to individuals, than pure repression). Also it forces historians to seriously consider the competing strategies put forward by rival agents rather than adopting a binary logic contrasting innocents with culprits. This is especially true given the lack of clearly defined rules when monitoring cases of corruption in the context of warfare which created extraordinary situations.

The chapters in this volume suggest that a broad consensus existed among various social groups regarding the definition of corruption in the management of tax revenue until the 1750s. This consensus is visible in the debates where those involved levelled at each other similar criticisms praising or blaming venal acts or altruistic services motivated by love of the king or the community. No substantial divergence can be detected between the definitions of fraud put forward by moral and legal theoreticians and agents on the ground, as revealed in letters, interrogations and indictments. There was no difference either between the discourses of merchants and bankers and members of the nobility, at least when they can be clearly identified (Bernsee, Félix, Legay, Malaprade, Velde, Winton).

An examination of how and why the common culture about corruption and its repression came to be contested and considered as the ideology of an archaic and aristocratic ethos detrimental to the both the interests of the ruler and the nation still remains to be undertaken. Before the French revolution, the relationship between lawful and unlawful access to the ruler's money, both in monarchic or republican states, had already initiated reforms of the fiscal state. Their chronology, however, varied from place to place. As a fiscal military state, England ranked among late starters, at least until the English civil war which, like the Dutch Revolt, initiated substantial transformations in taxation and tax collection, the organisation of credit and access to markets (Dickson, Neal 2000, Coffman 2013, T'Hart 2014), and eventually the system of procurement (Buchet 2013, Knight and Wilcox 2010). Elsewhere, pragmatism was most often the rule 
where rulers faced the alternative between monopoly and competition and, in general, direct administration or private intermediation. When public temporarily won over private, such as in Spain and France, governments usually justified their choice with help of an anti-corruption discourse. By and large, however, fiscal policy was less concerned with rooting out fraud than with maximising of returns, through securing better terms in contractual arrangements, and the reduction of asymmetric information by access to data on specific sources of revenue and expenditure. The existence of hybrid forms combining direct administration (régie) and tax farms, or monopoly and competition, confirms the flexibility of the relations between the private and public spheres. In this respect, the chapters in this volume contribute current reassessment of the notions of decline or backwardness of certain polities (Spain, Sweden) or, as in the case of France, the rationalisation of social action.

The cases studied in this volume show that the fiscal pressure of warfare, the political impact of military victory or defeat, the circulation of credit instruments and the refinancing of war debts opened up avenues for personal enrichment and fraud, and triggered anxieties and anger at the corruption of society and values. Hume's famous warning in his Essay on Money (1751) as to whether the state would kill debt or debt kill the state is, perhaps, the most striking statement about the permanence of factional attitudes towards the rise of the tax state and the transition to the modern fiscal state (Bonney), both in Britain (Hoppit 1990) and in Europe at large (González Enciso 2016). The clash reveals a lot about the destructive impact of warfare but, even more, about is creative dimension, especially its effects on political stability and economic development (O'Brien 2017). In the period covered in this volume, however, the military revolution and its potential reward for rulers seemed to have petted out in long wars of attrition with slow or uncertain results on the balance of power and the European state system (Kennedy). Yet the short-term results of the ongoing competition pitting dynastic, mercantile and confessional interests against each other fostered reflections on the sources of power and the comparative costs and benefits of European various polities and types of fiscal governance (Montesquieu 1750, Bonney 1995, Félix 2013).

As a matter of fact, polities tried to learn from their allies and competitors. Under pressure, rulers felt compelled, often unsuccessfully or at least slowly, to graft on foreign models to tackle domestic problems. Several case studies in this volume confirm that Louis XIV's wars constituted a major turning point in the attitude towards public good and private interest, but also that resumption of international warfare in the 1740s suddenly acted as another crucial period on the route towards the modern discourse and response to corruption. The evolution of monetary sovereignty in the Low Countries (Legay), the call on French tax farmers to establish a Regie of taxes in Prussia (Bernsee), the suppression of tax farming in 
the Dutch Provinces (Kerkhoff) and Spain (González Enciso), the role of foreign alliances in fiscal policy in Sweden (Winton) show beyond doubt that institutional change cannot be understood in an hermetically-sealed environment where change was impossible. As time went by, rulers and the public gained access to information about available resources and method of extracting and even increasing them. Under the pressure of war, polities were compelled to cherrypick and adopt components of foreign models. After all, Edmund Burke's crusade against corruption in Britain consciously built upon Necker's policy of cuts on expenditure, or the so-called economical reform. Conversely, Necker made clear that the British political model inspired his policy to remedy the constraints of war finance by accessing international credit markets and the pillars implementing credible commitment, notably publicity of royal accounts (Félix 2013).

Necker's refusal to accept the traditional and substantial gift - or pot-de-vin offered to the finance minister by the tax farmers when contracting the new lease for the collection of tax exemplifies the changes at work in the culture and the practice of corruption in the management of finances. Like many other $18^{\text {th }}$ century reformers across Europe, Necker could not modernise overnight the complex institutional canvass which framed early-modern relations between service to the ruler, personal profit, and public good. The modern definition of corruption and the tools to fight it had yet to be formulated by polities, implemented by government and internalised by fiscal agents. From the 1750s, however, the transition was supported by new theories about private interest and the accumulation of wealth, notably by the likes of Mandeville with his Fable of the Bees (Hundert 2005), the physiocrats and their fight against private financiers and for the abolition of mercantile regulations), Adam Smith's division of labour and invisible hand (Hill 2006), and Jeremy Benthams' Panopticon (Foucault, 1977). Still, the French Revolutionary and Napoleonic Wars and the Pax Britannica were to play a crucial role in activating the modern paradigm of corruption and implementing the relevant practices to fight it.

Needless to say, the chapters in this book act as spotlights on the wide-ranging question of private interest and the rise of the fiscal state. They do not intend to offer a comprehensive analysis of the various issues relating to corruption over time and across space in early modern Europe, but to identify some key problems set in different contexts, and, hopefully, stimulate further research in the field. Some of the papers presented in 2015 have not been included in this volume, either because their authors discussed their published or unpublished findings (Martinez, Waddell) on-going research (Knights) ${ }^{1}$. In the volume, European polities are unequally represented, partly because the organisers drew upon

${ }^{1}$ See the conference programme at http://www.reading.ac.uk/fiscal-history/ 
established networks of experts on private interest (Contractor State) and corruption (Anticorrp in Netherlands, VENACORRU and DINACOR in Spain), partly because of their inability to attract or identify other experts from elsewhere countries. Consequently, the many aspects of corruption in the management of early modern finances could not be fully addressed. Two areas in particular have not been much explored here. One concerns the connections between the theories and practices of corruption. The other relates to the impact of the Reformation on individual and institutions in the age of the confessional state. However, the reader will find useful references to the most recent literature on these aspects in the various chapters.

As this book suggests, crises and institutional change proceed from agency and its impact on the correlation between discourses and practices concerning the definition of power, its distribution and access to it. In the wake of the financial crisis of 2007-08 it hard to assess whether new regulations, criminal convictions and fines imposed on corporate agencies and private actors will re-form or redefine relations between public good and private interest. It is even harder to forecast their future in the context of Brexit and Trumpism. At the very least the challenges ahead confirm the relevance of studying the ways in which early modern polities dealt with their wars within.

\section{REFERENCES}

Acemoglu, D. and Robinson, J.A., 2013. Why nations fail: The origins of power, prosperity, and poverty. Broadway Business.

Andújar Castillo, F. \& Ponce Leiva, P. ed.: 2016. Mérito, venalidad y corrupción en España y América, siglos XVII y XVIII. Valencia: Albatros.

Artola Renedo, A., \& Dedieu, J.P., 2011. Venalidad en contexto. Venalidad y convenciones políticas en la España moderna. In El poder del dinero. Ventas de cargos y honores en el Antiguo Régimen. Edited by Andújar Castillo, F., $\&$ Felices de la Fuente, M.M. Madrid: Biblioteca Nueva, p. 29-45.

Bell, D.A. 2009. The cult of the nation in France: Inventing nationalism, 16801800. Harvard University Press.

Bonney, R., 1995. Economic Systems and State Finance: The Origins of the Modern State in Europe 13th to 18th Centuries. Oxford: Oxford University Press.

Bonney, R. ed., 1999. The rise of the fiscal state in Europe c. 1200-1815. Oxford: Clarendon Press. 
Bowen, H.V., 2013. The contractor state, c. 1650-1815. International Journal of Maritime History, 25(1), 239-274.

Braddick, M.J., 2000. State formation in early modern England, c. 1550-1700. Cambridge: Cambridge University Press.

Brewer, J., 1989. The sinews of power: war, money and the English state 16881783. London: Unwin Hyman.

Buchan, B. and Hill, L., 2014. An intellectual history of political corruption. New-York: Palgrave Macmillan.

Buchet, C., 2013. The British navy, economy and society in the Seven Years War. Woodbridge : Boydell Press.

Bucholz, R.O., 2018. Venality at court: some preliminary thoughts on the sale of household office, 1660-1800. Historical Research, 91(251), pp.61-97.

Coffman, D.M., 2013. Excise taxation and the origins of public debt. Palgrave Macmillan UK.

De Vries, J. and Van der Woude, A., 1997. The first modern economy: Success, failure, and perseverance of the Dutch economy, 1500-1815. Cambridge University Press.Dickson, P.G.M., 2017. The Financial Revolution in England: a study in the development of public credit, 1688-1756. London: Routledge.

Dickson, P.G.M. 1967. The Financial Revolution in England. A Study in the Development of Public Credit, 1688-1756. London: Macmillan.

Doyle, W. 1996. Venality: The Sale of Offices in Eighteenth-Century France. Oxford: Oxford University Press

Doyle W. 2004. Changing notions of public corruption, c.1770 to c.1850. In Corrupt Histories: 83-95. Edited by E. Kreike and W. Chester Jordan. New York: University of Rochester Press.

Doyle, W, ed. 2012. The Oxford Handbook of the Ancien Régime. Oxford: Oxford University Press.

Dubet, A. \& Legay, M.L. 2011. La comptabilité publique en Europe. Rennes: PUR. 
Ertman, T., 1997. Birth of the Leviathan: Building states and regimes in medieval and early modern Europe. Cambridge: Cambridge University Press.

Félix, J. 2013. The problem with Necker's Compte-rendu (1781). In The crisis of the absolute monarchy: from the old regime to the French Revolution: 107125. Edited by J. Swann, J. Félix. Oxford: The British Academy/Oxford University Press.

Félix, J. 2012. Finances. In Doyle, 2012: 75-92.

Félix, J., 2015. Finances. Paths to Fiscal Transparency. Histoire \& mesure, 30 (2), pp.3-22.

Foucault, M., 1979. Discipline and Punish, Trans. by Alan Sheridan. New York: Vintage.

González Enciso, A. 2016. War, Power and the Economy: Mercantilism and state formation in 18th-century Europe. London: Routledge.

Gorski, P.S., 2003. The disciplinary revolution: Calvinism and the rise of the state in early modern Europe. Chicago and London: University of Chicago Press.

Graham, A., 2015. Corruption, Party, and Government in Britain, 1702-1713. Oxford: Oxford Historical Monographs.

Hill, L., 2006. Adam Smith and the theme of corruption. The Review of Politics, 68(4), pp.636-662.

Hoenderboom (M.P.) y Kerkhoff (A.D.N.), "Corruption and Capability in the Dutch Republic: The Case of Lodewijk Huygens (1676)", Public Voices, núm. X-2, 2008, p. 7-24.

Hoppit, J., 1990. Attitudes to credit in Britain, 1680-1790. The Historical Journal, 33(2), pp.305-322.

Hoppit, J.. 2012. Reformed and Unreformed Britain, 1689-1801. In Doyle 2012: 506-21.

Hundert, E.J., 2005. The Enlightenment's fable: Bernard Mandeville and the discovery of society (Vol. 31). Cambridge: Cambridge University Press 
Kerkhoff, T., Kroeze, T., \& Wagenaar, P. eds. 2013. Corruption and the rise of Modern Politics in Europe in the Eighteenth and Nineteenth Centuries: A Comparison between France, the Netherlands, Germany and England. Journal of Modern European History 11-1: 19 et sq.

Kleer, R.A., 2017. Money, Politics and Power: Banking and Public Finance in Wartime England, 1694-96. Oxford: Oxford Universoty Press.

Knight, R. and Wilcox, M.H., 2010. Sustaining the fleet, 1793-1815: War, the British Navy and the contractor state. Woodbridge: Boydell \& Brewer.

Knights, M. 2017. Anticorruption in Seventeenth- and Eighteenth-Century Britain. In Kroeze, R., Vitória, A. and Geltner, 2017: 181-196.

Kroeze, R., Vitória, A. and Geltner, G. eds., 2018. Anti-corruption in History: From Antiquity to the Modern Era. Oxford: Oxford University Press.

Legay (Marie-Laure) dir.: 2010, Dictionnaire historique de la comptabilité publique, 1500-1850, Rennes, PUR.

Linton, M.A., 2001. The politics of virtue in Enlightenment France. Palgrave Macmillan.

Mandeville, B., 1924. The Fable of the Bees: Or, Private Vices, Publick Benefits: By Bernard Mandeville. With a Commentary Critical, Historical, and Explanatory by FB Kaye. Clarendon Press.

Neal, L., 2000. How it all began: the monetary and financial architecture of Europe during the first global capital markets, 1648-1815. Financial history review, 7(2), pp.117-140.

O'Brien, P., 2005. Fiscal and financial preconditions for the rise of British naval hegemony, 1485-1815.

O'Brien, P.K., 2018. The costs and benefits of mercantilist warfare. Financial History Review, 25(1), pp.97-112.

Parrott, D., 2012. The business of war: Military enterprise and military revolution in early modern Europe. Cambridge University Press.

Schumpeter, J. The Economics and Sociology of Capitalism. The Crisis of the Tax SAteTax state. In Navies and State Formation. The Schumpeter 
Hypothesis Revisited and Reflected: 21-78. Edited by J.G. Backhaus. Berl;n: Lit Verlag.

Storrs, C. ed. 2008. The Fiscal-Military State in Eighteenth-Century Europe. Essays in honour of P.G.M. Dickson, Ashgate.

T'Hart, M. 2014. The Dutch wars of independence: warfare and commerce in the Netherlands 1570-1680. London: Routledge.

Tilly, C. 1990. Coercion, capital and European states. AD 990-1992. WileyBlackwell.

Waquet, J.C., 1992. Corruption: ethics and power in Florence, 1600-1770. Pennsylvania State University Press.

Weber, M., 2013. From Max Weber: essays in sociology. London: Routledge.

Yun-Casalilla, B., O'Brien, P.K. and Comín, F.C. eds., 2012. The Rise of Fiscal States: A Global History, 1500-1914. Cambridge University Press. 